\title{
Pastoral care to migrants as care at the 'in-between' and 'liminal' home away from home: Towards public pastoral care to migrants
}

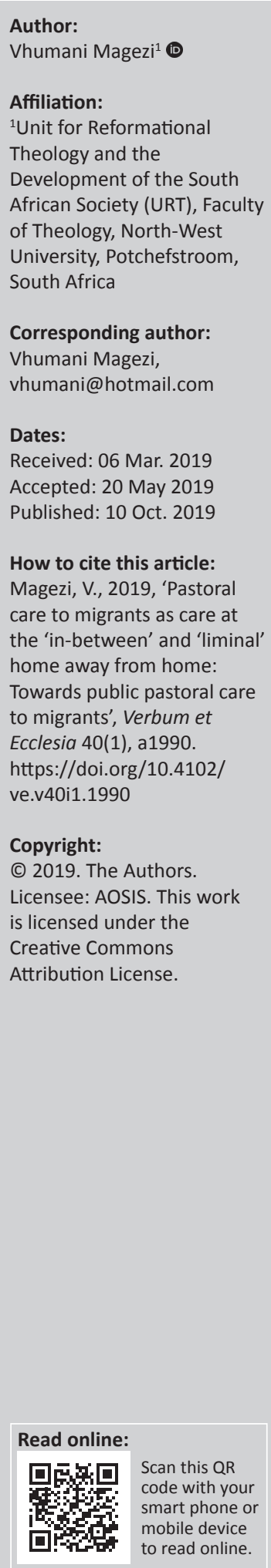

Migration is one of the greatest challenges in recent times. Churches, like other sectors of society, are expected to contribute. Pastoral care as a frontline ministry that forms a link with society is expected to develop strategies for effective pastoral caregiving. Understanding the challenges of migrants to appropriately intervene requires a relevant diagnostic and assessment framework. This article proposes the notion of 'life in-between' as an assessment and guiding pastoral care intervention framework. The article argues that pastoral care to migrants should assume a public pastoral care approach to address their holistic needs and address the public dimension of care. Within this context, life at the 'in-between' is conceived physically, metaphorically, spiritually, emotionally and theoretically. The pastoral care provided to migrants as people at the 'in-between' is enriched by the notion of the human web as opposed to only focusing on the human document within the complexities of migrant care.

Intradisciplinary and/or interdisciplinary implications: The study focuses on practical theology, but with a specific focus on the sub-discipline of pastoral care. It examines the phenomenon of migration and how it can be responded to. It focuses on designing a model for assessment and intervention in migrant care.

Keywords: public pastoral care; pastoral care; migrants care; life in-between; human web; migrants ministry; migrants pastoral care.

\section{Introduction}

Some theologians considered the challenge of migration to be a sign of the times (Gruber \& Rettenbacher 2015:1-4). Castles and Miller (2009:2-3) rightly described our present time as an age of migration. Hang (2018:279) observed that migration has been studied from various academic disciplines including politics, international relations, theology and many other areas. Accordingly, pastoral care - like any other theological discipline - should respond. Responding to migration is complex, with no simple and straightforward approach. It calls for flexibility, zigzagging and adopting a public pastoral role. As a contribution to the discussion on pastoral care to migrants, the article first positions migration within the context of public pastoral care. Secondly, it develops a pastoral assessment and hermeneutical framework for ministry to migrants. Thirdly, it suggests some pastoral care approaches to migrant contexts. The research is based on a literature study.

To locate migrant ministry within pastoral care compassion, Louw (2016a) in the article entitled "The refugee dilemma and migrant crisis: "Charity begins at Home" or "Being Home to the Homeless"? The paradoxical stance in pastoral caregiving and the infiltration and perichoresis of compassion' argued that:

Compassion displays the hope of unconditional love and pity. Compassion in Christian spirituality is not a fleeting emotion of empathy; it is a new state of being and condition; it displays the mindset of Christ's vicarious suffering on behalf of the other; it exemplifies a hospital place and room for displaced human beings - even for displaced perpetrators.

Louw (2016:9) clarified that 'Compassion as a way of life and new state of being and mind (ethos) is about a habitus of caregiving and comfort'. In placing locating ministry within pastoral care, Louw (2016:9) clarified that: Cura animarum starts on a practical level caregiving with, (1) an unqualified grassroots encounter with all stakeholders in the refugee and migrant dilemma, (2) it moves to mutual understanding and interpretation beyond the hermeneutics of suspicion and prejudice, (3) it promotes negotiation with all parties involved; it alters social structures of exclusive participation to inclusive participation, (4) it applies a pastoral polity of presence: a compassionate being with them, where they are and (5) it practices an hospitable infiltrating and osmotic perichoresis of making room or home for the homeless. (p. 10) 
Noting the theoretical formulations of Louw (2016a:9), Magezi (2017b:240-241) posed a question that challenges theoretical formulation in migration to practical application. He asked, 'How does one proceed from a theoretical reflection to a practical dimension and intervention for a ministerial formation that is informed by the theological notion of eschatological home?'. In response to this question, Magezi (2017b:245) proposed a migrant ministry responsive model that encourages co-existence between host country churches and migrant churches through a 'practical theological imagination of home as a responsive theology for migrant care and ministry'.

Louw's (2016) argument for compassion and Magezi's (2017b) proposal for an imaginative practical response model suggest a focus on making pastoral care public. Indeed, migrant ministry is a public pastoral care endeavour. Osmer and Schweitzer (2003:218) usefully described the task of public practical theology in three ways: firstly, it is about ensuring that the public is one of the audiences of practical theology. Secondly, it is to ensure that practical theology includes everyday concerns and issues in its reflection. Thirdly, practical theology should facilitate a dialogue between theology and contemporary culture. Pastoral care as cura animarum [cure of souls] is shifting from individual intrapsychic focus to addressing public issues (Louw 2014; McClure 2012; Miller-McLemore 2004, 2005, 2018; Ramsay 2004, 2014). Miller-McLemore (2018:312) highlighted three trends behind this shift. These are the interest in congregational studies, the call for a new public theology and the rise of liberation movements. Thus, shifting pastoral care to public pastoral care entails developing practical ways of healing aimed at public space issues (Leslie 2008:21) such as migration.

\section{Migration and pastoral care challenge}

Migration is one of the greatest global challenges of our time. Migration has been made easy by globalisation, including easy travelling across countries (Skeldon 2013; United Nations Human Rights Office of the High Commissioner 2013). Various sectors of society, including national and international bodies such as United Nations (UN) agencies, the European Union, international organisations such as the International Organization for Migration (IOM), church bodies such as Councils of Bishops and the World Council of Churches, have been exploring ways to effectively address the challenges posed by migration. ${ }^{1}$ The challenge of migration is complex. The complexity of the migration situation was rightly expressed by the Council of Bishops' Conferences of Europe (CCEE) (2016:1-2), who noted that 'the integration of migrants and refugees is a complex and multi-faceted phenomenon for which no single model applies, but different experiences related to the needs and possibilities of the receiving territory' (CCEE 2016:1-2).

1.For statistics on migration, kindly see Magezi's (2017) presentation of data from the UNHRC, the IOM and other international organisations.
The interventions being implemented to address migration are documented by organisations such as the IOM (2015) and UNHCR Interventions in Situations of Internal Displacement (2018) and many others. Faith-based organisations, particularly churches, have also been involved in efforts to address migration in different ways. My interest in this article is on churches' contribution to addressing migration challenges. The churches have been involved in migration interventions, including mobilising citizens to put pressure on and lobbying governments particularly in Europe (Stourton 2015); the Pope's Vatican Dicastery for Integral Human Development (created by Pope Francis himself) to raise awareness of this issue and to persuade countries (Guzik 2018); Council of Bishops pastoral letters (CCEE 2016; United States Conference of Catholic Bishops 2003); issuing advocacy statements; establishing church non-governmental organisations; forming networks and coalitions; and providing congregational pastoral care ministries. Within these diverse church ministries and responses, this article's focus will be on pastoral care.

The church's interventions to migration are done from a Christian perspective. Baggio (2011:1-2) advised that migration requires serious theological reflection. Magezi (2018) in his doctoral thesis demonstrated that migration is indeed a theological issue that calls for a thorough theological reflection. He analysed the various theological approaches and classified them into five broad categories before proposing an integrated ministry model. These categories are:

1. a systematic approach that focuses on practical responses from pastoral care that is limited to particular social contexts

2. the approach of theological motif and ministry praxis from single biblical texts

3. a systematic response that focuses on Israel in the Old Testament as a paradigm of how the native churches and hosting nations should treat migrants

4. urban mission scholars' systematic approach to the Church's incarnational ministry embedded in their larger focus on migration within the context of the Great Commission

5. a systematic approach that focuses on doctrinal formulations that respond to migration challenges. (pp. 14-15)

In his own work, Magezi (2018:iv) proposes a 'Public Operative Ecclesiological Model (POEM)' of ministry to migrants. He argues that POEM is about a public church that understands its public practical theological role to be a community and socially responsive church. To ensure that churches practically engage in migration ministry, the Union Chapel's (2017) concept paper entitled 'Theologising on migration in Europe' usefully commented that:

The question is: in which ways can the scripture inform, help, and motivate Christians' praxis on migration dynamics. We must not allow our reading of scripture to nourish the division of the world in migrations and non-migrants. (p. 2)

The concept paper clarifies that the 'purpose of theologising on migration should be to inform and transform praxis and 
to move the policy debate forward by directing attention to questions of justice, community, responsibility and obligation' (Union Chapel 2017:2). The challenge for theology to engage with public issues such as migration is the focus of public theology. Vanhoozer and Strachan (2015:17-18) observed that public theology is first and foremost a reaction against the tendency to privatise the faith, restricting it to the question of an individual's salvation. An individualised and privatised approach to theology and Christianity renders theology and Christianity irrelevant in the world. Therefore, migration challenges pastoral care (cura animarum) to pastorally engage this public and social issue head-on. Within global pastoral care reflection, there is recognition and a shift of pastoral care to engage public issues (Lartey \& Sharp 2015; Leslie 2008; Louw 2014; Miller-McLemore 2005; Ramsay 2004). Pastoral care should shepherd and nurture migrant people who are experiencing pain and other life challenges.

The question that arises from the preceding discussion is: how can pastoral care to migrants be performed in such a manner that it ensures holistic care ${ }^{2}$ The researcher argues that pastoral care to migrants should assume a public pastoral care approach to address their holistic needs and address the public dimension of care. Three assumptions inform this argument (Union Chapel 2017):

1. Firstly, the challenges posed by migration both to the migrants themselves and host communities are complex. The challenges affect their total being (all dimensions of their lives). Hence, a relevant pastoral intervention should adopt a systemic approach. A systemic approach entails shifting from focusing only on the human document to an individual living in a human web. Miller-McLemore (2018:318) explains that this entails intervening pastorally on congregational, social and cultural levels in a manner that demands the same kind of extended attention, discussion and programmatic strategising that have given to individual listening.

2. Secondly, a systemic approach entails addressing holistic needs of migrants, which suggests that pastoral care should adopt a public pastoral care stance. Leslie (2008:81) advised that pastoral theology informed by public theology engages in public debate, engages life issues and develops practical strategies for healing, sustaining, guiding and liberating individuals, cultures and the natural order in the public space.

3. Thirdly, the space and position where hosts interface and interact with migrants to exercise hospitality are at grassroots level such as community (neighbourhood and other related social spaces) and at congregational level. Hence, pastoral care to migrants should entail empowering pastors and congregations to provide effective care. 'Part of the function of a pastoral theology is to equip these practices with the intelligence and wisdom needed to move from the immediate crisis intervention to longer term resolutions'. (p. 4)

To locate the argument of a responsive public pastoral care ministry that addresses migrants' needs within a theoretical framework, the researcher departs from the premise that

2.For a discussion on pastoral care as holistic care, see the discussion on how pastora care ministry should provide care for the pubic in Louw 2014; McClure 2012; MillerMcLemore 2004, 2005, 2018; Ramsay 2004, 2014. migrants are people living an 'in-between life' (Magezi 2016:88-90). This refers to life between their home country and the host country where they are presently positioned. In such a context, pastoral care should assume a public pastoral care approach whereby caregiving entails holistic (whole person care-soul care-nephesh care). The caregiving process should be informed by the existential realities and complexities of the human web. These complexities include considerable tension between original homeland norms, values and practices and the practices, norms and values of the host country.

\section{An assessment and hermeneutical model for understanding migrant challenges at the 'in-between' space The notion of an assessment model within a process of understanding in pastoral care}

An assessment or diagnostic model helps to explain and understand a situation more clearly. A diagnostic chart is about a hermeneutical understanding of how life issues are linked and interconnected (Louw 1998, 2016). Magezi (2017b), citing Louw, noted that:

The development of a diagnostic chart is based on the presupposition that insight into the systemic networking of attitudes and paradigms helps individuals to consider different strategic options, especially when one has to link the options to basic theological categories. (p. 241)

A diagnostic model helps one to see the bigger picture (Magezi 2017b):

Seeing the bigger picture brings about a kind of soberness and realism and opens up options that create a sense of 'hope'. A diagnostic chart helps one to see the bigger picture, the networking dynamics of life as an existential and qualitative category. Within this framework, life is a web where the dynamics and structural interplay between various situations, experiences and relationships should be understood as part of a reality within the global village. Complexity is the norm. (p. 241)

The CCEE (2016:1-2) noted that responding to migrants is complex. There is no simple and straightforward approach. It calls for flexibility and multiple strategies. Addressing the needs and challenges of migrants entails addressing the whole person in his or her entirety. They explain that 'the person may be in need of a job and a house, but also of the love of a family and spiritual support' (CCEE 2016). As stated by Magezi (2017b):

A model therefore helps to widen one's perspective and demonstrates the complexity of the migration crisis. It also helps one to see the big picture, which raises awareness on the complexities of the situation, and shows that an 'either-or' approach is inappropriate. (p. 243)

Thus, a diagnostic model helps to interpret and understand the situation of people. Dreyer (2005), in her essay entitled 'Reflections on Donald Capps' hermeneutical model of pastoral care' usefully explained that: 
Hermeneutics forms the heart of the theological enterprise and is therefore interdisciplinary by nature. All theology, also practical theology and pastoral care, is a hermeneutical activity since it is about how one should understand and how one should communicate in order for the recipients to best understand what is being communicated. (p. 114)

Bhugra (2004), in his essay entitled 'Migration, distress and cultural identity' developed a conceptual model of understanding the changes that migrants go through. Bhugra (2004) argued that:

When people migrate from one nation or culture to another, they carry their knowledge and expressions of distress with them. On settling down in the new culture, their cultural identity is likely to change and that encourages a degree of belonging; they also attempt to settle down by either assimilation or biculturalism. (p. 129)

This puts migrants in some kind of middle point of 'neither here nor there'. While they are physically in another country, at the same time, they are deeply connected to their homeland. Magezi (2016:91-92) described this life of migrants as 'being in a web' where (Magezi 2017b):

$[T]$ he dynamics and structural interplay between various situations, experiences and relationships should be understood as part of a reality. One has to contend with complexity and explore options to meaningfully cope within the situation. (p. 241)

Life in this situation is in flux, where people find themselves in 'in-between' situations.

Bhugra (2004:135) illustrated the changes that migrants undergo in a model (Figure 1). The diagram shows that migrants undergo changes at social and personal levels.

\section{Bhugra (2004) argues that:}

When individuals migrate, they do not leave their beliefs or idioms of distress behind, no matter what the circumstances of their migration. Their beliefs influence their idioms of distress, which influence how they express symptoms and their helpseeking behaviour. (p. 134)

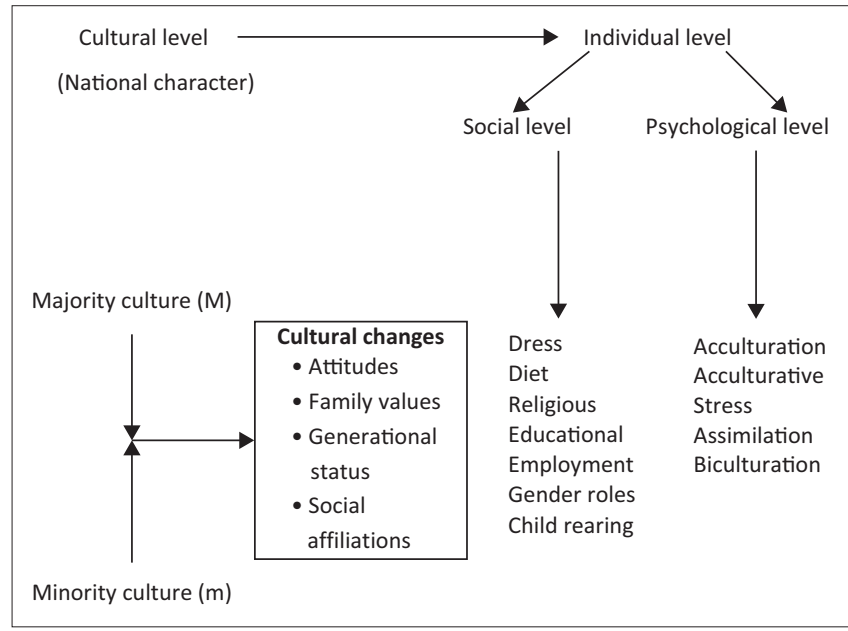

Source: Bhugra, D., 2004, 'Migration, distress and cultural identity', British Medical Bulletin 69(1), 129-141. https://doi.org/10.1093/bmb/ldh007

FIGURE 1: Social and psychological issues that migrants experience.
He added that as migrants get acculturated,

Some aspects of identity are likely to change, including the concept of self, and this will be dependent upon the cultural context. A person's identity is defined as the totality of one's self - formed by how one construes oneself in the present, how one construed oneself in the past and how one construes oneself as one aspires to be in the future. (Bhugra 2004:134)

It is clear from Bhugra's observation that life of migrants is at the 'in-between'. Understanding this life space of the human web of migrants requires that pastoral care shifts from focusing solely on the person to paying careful attention to communal contextual (Lartey 2003:153-165). MillerMcLemore (2018) advises that in this context of the human web, pastors have to possess multiple skills. For instance, pastors have to 'know how to analyse communal resources, enter and organize communities for action, and balance ministry to individuals in crisis with social advocacy' (MillerMcLemore 2018:318).

\section{Towards an assessment and hermeneutical model for migrant pastoral care needs}

To provide pastoral care to migrants in their situations (i.e. their human web), one has to have insight and understanding of their needs and challenges. The needs are diverse, hence the pastor has to develop some insightful ways of assessing and addressing them. To develop such an understanding, an assessment model is required that will assist in understanding the situation to provide effect care. The model is summarised in the diagram below (Figure 2).

The assessment model attempts to present and reflect on the different dimensions of life, including physical, social, emotional, relational and spiritual. The arrows indicate movements that also have an impact on the life of the individual. The life of migrants is lived at an 'in-between' space. There are multiple dimensions of life at the

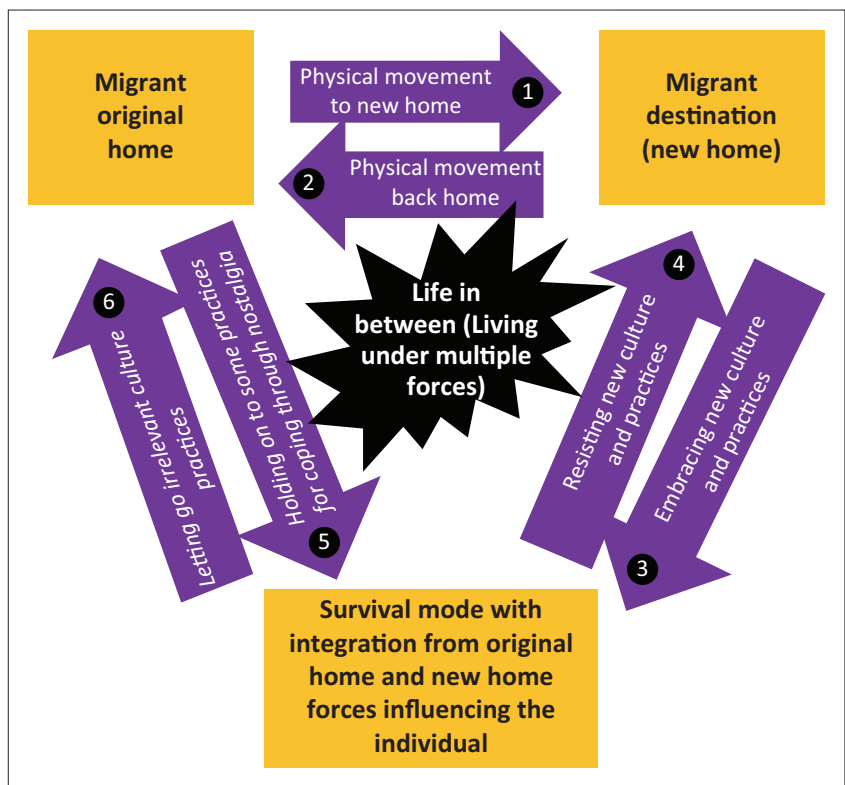

FIGURE 2: Assessment and hermeneutical considerations model for understanding migrant challenges - life at the in-between. 
'in-between', all pointing to one aspect - life lived between geographical spaces. The notion of 'in-between' has physical, metaphorical, spiritual and emotional, and theoreticalconceptual dimensions.

Physically, life at the 'in-between' entails physical movement or shifting of an individual from time to time from the homeland to a new location and back, particularly for economic and professional migrants. For instance, a Kenyan migrant working in the United States moves 'in-between' these two countries. One has to set aside financial resources to meet these travelling costs. Metaphorically, life at the 'inbetween' is a state of existing between two forces of influence pulling a person in two directions. It denotes a space of tension where allegiances, commitments, investments and the entire being are neither here nor there. It is a space of 'I don't belong permanently to either'. At a spiritual and emotional level, life at the 'in-between' is a state of emotional tension where an individual is torn between embracing the new culture, practices and norms of the host country and 'letting go' of those of the country of origin. It is characterised by spiritual confusion, dissonance and grief as spiritual being and values are confronted, challenged and altered. Just like life at the 'in-between' metaphor, the metaphysical world of the individual is thrown into turmoil. This particularly happens for adults, especially men from patriarchal cultures, who in most cases are cultural custodians. At a theoretical and conceptual level, life at the 'in-between' denotes the life in the new environment competing with the previous life experiences and foundations. Just like metaphorical 'inbetween', it is life's 'force field' that is sustained by the existential pressure and competition between two influences in life, resulting in the formation of a new cultural blend. It is a space of 'liminal existence' where something new is forming, but it is characterised by uncertainty. Bhugra (2004:135) calls it biculturation. The principle of liminality was first described by Van Gennep (1960) and later developed by Turner (1967, 1969). Turner (1969:94) observed three phases in transition experiences: separation - losing an old world; margin (liminality) - entering an unknown world; and re-aggregation - re-emerging into a new world. For Turner (1967:94), the liminal function is the period of transition from 'one type of stable or recurrent condition that is culturally recognized' to another that is not recognised.

So, how is this life of 'in-between' lived and what are the issues that pastoral care providers should pay attention to?

Arrows 1 and 2: Arrow 1 (Figure 2) indicates directional movement of migrants from country of origin to new destination. When they arrive, they exploit the opportunities and seek meaningful existence in that country. However, periodically, these people would travel back to their countries of origin (arrow 2, Figure 2). This is particularly the case with professional migrants who emigrate to seek better opportunities. While in foreign countries, the people sometimes engage in investment and construction projects that they travel to oversee in their countries of origin. Physically travelling to new destinations (arrow 1) and back to their home country (arrow 2) is in most cases expected by extended family members. Failing to travel back from time to time can be construed as uncaring and betrayal of the extended family, particularly among African migrants, which causes emotional pain, dissatisfaction and despair. At the same time, the moving back and forth is expensive for the migrant, which puts the individual under immense economic pressure.

What role then can pastoral care play in such a case? In most cases, migrants move without having been adequately made aware of the challenges, expectations and responsibilities awaiting them by virtue of being in a foreign country particularly overseas. There is encouragement in pastoral letters for migrants to continue looking back to support their people. The United States Conference of Catholic Bishops (USCCB) (2003) 'Pastoral Letter Concerning Migration' encourages that:

Special encouragement should be given to migrants to be faithful to their spouses and families and to thereby live out the sacrament of marriage. Support of the family that is left behind is also needed. Migration under certain conditions can have a devastating effect on families; at times, entire villages are depopulated of their young people. (ch. 3)

In such a case, pastoral care should perform a preparatory role. At the countries of origin, pastoral care would entail equipping and empowering migrants with information about the realities of being a migrant. The USCCB (2003) recommends that:

As migrants leave their homes, pastoral counselling should be offered to help them to better understand these realities and to consider alternative options, including the exploration of available legal means of immigration. (ch. 3)

Therefore, moving back and forth is an aspect that pastoral caregivers should anticipate and address.

Arrows 3 and 4: Arrows 3 and 4 (Figure 2) denote migrants' interaction with their new environment to cope in the new situation. Arrow 3 is an individual's response to the new environment, including personal aspects such as dressing, employment, diet and child raising; social aspects such as acculturation and assimilation; and cultural aspects such as family values and status (Bhugra 2004:135). Arrow 4 indicates migrants' responses to the new environment. These responses may cause anxiety and depression because of, among other things, attempts to push back on new norms and values, struggling to adapt, and efforts to reinterpret life experiences in the light of the new environment.

Arrows 5 and 6: Arrow 5 (Figure 2) denotes spiritual norms, values and experiences imported through nostalgia to create an emotional buffer. There is often constant communication and linking with people in the country of origin. The individual keeps following up on trends and developments in the country of origin through news to maintain emotional and relational connection with the homeland. Arrow 6 (Figure 2) indicates largely communication and feedback to 
relatives in the country of origin. This includes feedback on progress, achievements and challenges.

The interactive arrows (Figure 2) indicate the interactions that happen as one tries to relate and adapt to the new environment. When people migrate, they take with them their culture, which, in turn, influences the way they live in a new environment. It is a kind of coping mechanism in a new environment. Bhugra (2004:130-136) explained that when individuals migrate, they do not leave their beliefs or idioms of distress behind, no matter what the circumstances of their migration. Their beliefs influence their idioms of distress, which influence how they express symptoms and their helpseeking behaviour. However, with acculturation, some aspects of these beliefs and practices change, including the concept of self. When two cultures of people come together, which is called acculturation, each of the cultures changes (Bhugra 2004:135). The cultures interact with one another to create a new one that is unique, but borrows from both cultures. A person then redefines himself or herself based on the past and the current experiences and interactions. In this process, some of the treasured things are lost, which sometimes causes pain because in reality one culture will dominate the other. Younge (2015) summed up the situation succinctly as follows:

Migration involves loss. Even when you're privileged, as I am, and move of your own free will, as I did, you feel it. Migrants, almost by definition, move with the future in mind. But their journeys inevitably involve excising part of their past. It's not workers who emigrate but people. And whenever they move, they leave part of themselves behind. Efforts to reclaim that which has been lost results in something more than nostalgia but, if you're lucky, less than exile. And the losses keep coming. Funerals, christenings, graduations and weddings missed - milestones you couldn't make because your life is elsewhere. (p. 1)

Life at the 'in-between' as indicated in the diagram (Figure 2) suggests that migrants' life is lived under several forces of influence that should be understood. There is an interaction and merging of the person's old experiences and new life experiences. The individual experiences new situations and environment, including buildings and infrastructure, relationships, social acquaintances and a new economic system, among others. This renders learned skills obsolete and in some instances it results in inversion of roles, when children adapt quickly and teach parents. There is also a need to quickly learn new skills for survival and many others things. A person see-saws between the new and old life physically, spiritually, emotionally and relationally. The pressure exerted on the individual should be understood by a pastoral counsellor. The situation is a human web that should be understood at multiple levels. The diagram (Figure 2) indicates some aspects that provide pointers on the issues to explore in pastoral caregiving. The interplay of these forces in migrant people should be understood to provide meaningful care. Church, as a convergence space in society and a subsystem of society, is called upon to provide effective pastoral care to migrants and other community challenges. 'Theologising on migration is at the service of both the church and the wider society. It should inform Christian praxis' (Union Chapel 2017:2). Theology places God and God's relationship with humanity and therefore the relationships of humanity within itself at the heart. Pastoral care as practical theology should develop strategies and approaches that address people's challenges in a holistic way.

\section{Towards pastoral care guidelines for migrants' care ministry}

Pastoral care discussions on migrants have tended to focus more on advocacy pronouncements and less on what can be done at local congregational level (Union Chapel 2017:2). Therefore, the following pointers seek to contribute to positioning pastoral care within a public response to migrants.

- Firstly, pastoral care to migrants should be holistic. The ministry should be designed in a manner that it addresses spiritual and physical needs of individuals. Migrants' needs are complex and diverse, including the need for documentation, family separation, need for food, trauma, accommodation and many others. Often the individual has all these needs at the same time. Thus, with the limited resources of many churches, there is a need to draw from existing networks. This entails that the pastor adopts a strategic role as a community or city networker, for instance, linking with civil society organisations providing relevant assistance (e.g. obtaining documentation). Pastoral care would also entail developing a linkage with relevant government departments dealing with migrants and having dedicated staff.

- Secondly a pastoral care should be attentive and seeing. This entails the development of pastoral skills and techniques to observe, identify and be sensitive to migrants' needs. Because of vulnerability and the desire to avoid being a burden, some individuals may decide to be silent. Therefore, the pastor should develop the skills to notice when people present unusual behaviour and intervene to assist.

- Thirdly, congregational koinonia should be strengthened to provide a support structure for people without relatives and family. Migrants experience loss of a familiar and supportive environment and they require support as they adjust to the new environment and culture. Developing and strengthening family enrichment, including establishing home groups, provides a sense of family, which provides a buffer for lost relatives and connections.

- Fourthly, pastoral care should include migrant education and empowerment. Because of exclusion by host communities, migrants sometimes tend to self-exclude and self-discriminate. This results in migrant enclaves where they form separate social networks. Because of their self-excluding nature, these networks may fan low self-perception. Pastoral care intervention of empowerment through pastoral education enrichment should be done. The themes should include a Christian understanding of citizenship, home, identity and other themes that address migrants' being. 
- Fifthly, pastoral care should also focus on congregational mutual learning. This entails creation of spaces for therapeutic conversations between host people and migrants. These conversations should engage in healing processes and Bible stories of family, hospitality and general life issues for catharsis.

- Sixthly, pastoral care should include preparatory education before leaving the country of origin. Before departing from countries of origin, migrants need to be made aware of the potential challenges that they may encounter and be equipped with basic life skills to cope as a migrant. This includes identifying church spaces where they can worship and receive practical support.

\section{Conclusion}

There is no formula for providing pastoral care in complex situations such as migration. However, one important principle that should guide caregivers is that the interventions should have a clear intentional public dimension to address physical needs. This challenges the pastoral caregiver to develop multiple skills beyond spiritual care to practical life skills, which sometimes causes pastors to feel inadequate. In such situations, Louw (2014) advised that 'the being' of the pastor, the 'embodiment' of care is more important than techniques. Resonating with Louw's emphasis on the 'being of the pastor', but emphasising a slightly different aspect, Miller-McLemore maintained that despite the evident shift from the focus on the human document to the human web (Miller-McLemore 2018) as well as the shift from private intrapsychic focus to public pastoral care (Miller-McLemore 2005) that pastoral caregivers are called upon, this shift points to different strategies of pastoral care. Despite this shift, one fundamental aspect of the discipline, which MillerMcLemore (2018:318) calls the trademark, namely empathy, has stayed constant. Empathy is the defining undergirding attitude and skill required to effectively provide care within complex situations like migrant situations.

\section{Acknowledgements Competing interests}

The author declares that he has no financial or personal relationships that may have inappropriately influenced him in writing this article.

\section{Authors' contributions}

The author is solely responsible for this article.

\section{Ethical considerations}

The article is a literature study with no ethical clearance.

\section{Funding information}

This research received no specific grant from any funding agency in the public, commercial or not-for-profit sectors.

\section{Data availability statement}

Data sharing is not applicable to this article as no new data were created or analysed in this study.

\section{Disclaimer}

The views and opinions expressed in this article are those of the author and do not necessarily reflect the official policy or position of any affiliated agency of the author.

\section{References}

Baggio, F.C.S., 2011, Planning for the pastoral care for migrants and refugees in a multicultural church, viewed 05 March 2019, from https://www.researchgate. net/profile/Fabio_Baggio/publication/281463905_Planning_For the Pastoral 08 ae 3 e121844b4de/Planning-For-the-Pastoral-Care-for-Migrants-and-Refugeesin-a-Multicultural-Church.pdf.

Bhugra, D., 2004, 'Migration, distress and cultural identity', British Medical Bulletin 69(1), 129-141. https://doi.org/10.1093/bmb/ldh007

Castles, S. \& Miller, M.J., 2009, The age of migration: International population movements in the modern world, Palgrave Macmillan, Hampshire.

Council of the Bishops' Conferences of Europe (CCEE), 2016, 'Rediscovering the gift of hospitality', Meeting of bishops and delegates responsible for the pastoral care of migrants of the Catholic Bishops' Conferences of Europe, Madrid, Spain, September 26-27, 2016, viewed 04 March 2019, from https://www.icmc.net/sites/default/ files/documents/press_release_rediscovering_gift_hospitality_en.pdf.

Dreyer, Y., 2005, 'Reflections on Donald Capps' hermeneutical model of pastoral care', HTS Theological Studies 61(1-2), 109-130. https://doi.org/10.4102/hts.v61i1/ 2.450

Gruber, J. \& Rettenbacher, S. (eds.), 2015, Migration as a sign of the times: Towards a theology of migration, Brill, Leiden.

Guzik, P., 2018, 'Communicating migration - Pope Francis' strategy of reframing refugee issues', Church, Communication and Culture 3(2), 106-135, https://doi. org/10.1080/23753234.2018.1478230

Hang, S.H., 2018, 'Migration in missiological research', International Review of Mission 107(1), 279-293. https://doi.org/10.1111/irom.12222

IOM, 2015, Migration initiatives - Regional strategies, viewed 04 March 2019, from http://publications.iom.int/system/files/pdf/migration_initiatives2015.pdf.

Lartey, E.Y., 2003, Living colour: An intercultural approach to pastoral care and counselling, Jessica Kingsley, London.

Lartey, E.Y. \& Sharp, M.A.M., 2015, 'Practicing public pastoral theologies in contexts of difference', Journal of Pastoral Theology 25(3), 133-134. https://doi.org/10.1080/ 10649867.2015.1123504

Leslie, K.J., 2008, 'Pastoral care in a new public: Lessons learned in the public square', Journal of Pastoral Theology 18(2), 80-99. https://doi.org/10.1179/jpt.2008. 18.2.005

Louw, D.J., 1998, Pastoral hermeneutics of care and encounter, Lux Verbi, Cape Town.

Louw, D.J., 2014, Wholeness in hope care: On nurturing the beauty of the human soul in spiritual healing, LIT, Wien.

Louw, D. J., 2016a, 'The refugee dilemma and migrant crisis: "Charity begins at home" or "Being home to the homeless"? The paradoxical stance in pastoral caregiving or "Being home to the homeless"? The paradoxical stance in pastoral caregiving
and the infiltration and perichoresis of compassion', HTS Teologiese Studies/ Theological Studies 72(2), a3267. http://doi.org/10.4102/hts.v72i2.3267

Louw, D.J., 2016b, 'Between xenophobia and xenodochia in an operative ecclesiology of home: The plight of refugees and migrants as challenge to a diagnostic approach in pastoral hermeneutics of caregiving', Unpublished paper.

Magezi, C., 2017a, 'Migration crisis and the church: A response to lacunae and considerations for Christian ministry engagement', Verbum et Ecclesia 38(1), a1671. https://doi.org/10.4102/ve.v38i1.1671

Magezi, V., 2016, 'Pastoral care within globalization as care at the in between: The dynamics of pastoral care and counselling for meaning and coping in a global context', in U. Elsdörfer \& T.D. Ito (eds.), Compassion for one another in the Global Village: Social and cultural approaches to care and counselling, pp. 80-95, LIT Verlag, Münster.

Magezi, C., 2018, 'Theological understandings of migration and church ministry models: A quest for holistic ministry to migrants in South Africa', PhD thesis, North-West University.

Magezi, V., 2017b, 'Glocal' and integrated churches within a practical theological imagination of 'home away from home': Towards a ministry of migrants and refugees in diaspora', Stellenbosch Theological Journal, 3(1), 227-250. http://doi. org/10.17570/stj.2017.v3n1.a11

McClure, B., 2012, 'Pastoral care', in B.J. Miller-McLemore (ed.), The Wiley-Blackwell companion to practical theology, pp. 269-278, Blackwell, Chichester.

Miller-McLemore, B.J., 2004, 'Pastoral theology as public theology: Revolutions in the "Fourth area"', in N.J. Ramsay (ed.), Pastoral care and counseling: Redefining the paradigms, pp. 45-64, Abingdon, Nashville, TN.

Miller-McLemore, B.J., 2005, 'Pastoral theology and public theology', in E. Graham \& A. Rowlands (eds.), Pathways to the public square: Practical theology in an age of pluralism, pp. 95-105, LIT Verlag, Münster. 
Miller-McLemore, B. J., 2018, 'The living human web: A twenty-five year retrospective', Pastoral Psychology 67(3), 305-321. https://doi.org/10.1007/s11089-018-0811-7

Osmer, R. \& Schweitzer, F., 2003, Religious education between modernization and globalization: New perspectives on the United States and Germany, Eerdmans, Grand Rapids, MI.

Ramsay, N.J., 2004, 'A time of ferment and redefinition', in N.J. Ramsay (ed.), Pastoral care and counseling: Redefining the paradigms, pp. 1-43, Abingdon Press, Nashville, TN.

Ramsay, N.J., 2014, 'Intersectionality: A model for addressing the complexity of oppression and privilege', Pastoral Psychology 63(4), 453-469. https://doi. org/0.1007/s11089-013-0570-4

Skeldon, R., 2013, 'Global migration: Demographic aspects and its relevance for development', Technical Paper no. 2013/6, United Nations Department of Economic and Social Affairs Population Division, viewed 27 March 2016, from http://www.un.org/esa/population/migration/documents/EGM.Skeldon 17.12.2013.pdf.

Stourton, E., 2015, 'Church takes strong stand on migration', viewed 04 March 2019, from https://www.bbc.co.uk/news/world-32477795.

Turner, V.W., 1967, The forest of symbols, Cornell University Press, New York.

Turner, V.W., 1969, The ritual process: Structure and anti-structure, Aldine, Chicago, IL.
UNHCR, 2018, 'interventions in situations of internal displacement (the 'IDP Footprint')', International Journal of Refugee Law 30(2), 339-354. https://doi. org/10.1093/ijrl/eey036

Union Chapel, 2017, Theologising on migration in Europe, viewed 04 March 2019 from https://www.unionchapel.org.uk/wp-content/uploads/2017/09/Theologyof-Migration-concept-paper.pdf.

United Nations Human Rights Office of the High Commissioner, 2013, Migration and human rights: Improving human rights-based governance of international migration, viewed 12 May 2016, from http://www.ohchr.org.

United States Conference of Catholic Bishops (USCCB), 2003, A pastoral letter concerning migration from the Catholic Bishops of Mexico and the United States, 22 January, viewed 04 March 2019, from http://www.usccb.org/issues-andaction/human-life-and-dignity/immigration/strangers-no-longer-together-onthe-journey-of-hope.cfm

Van Gennep, A., 1960, The rites of passage, Routledge, London.

Vanhoozer, K.J. \& Owen, S., 2015, The pastor as public theologian: Reclaiming a lost vision, Baker Academic, Grand Rapids, MI.

Younge, G., 2015, As migrants we leave home in search of a future, but we lose the past, viewed 05 March 2019, from https://www.theguardian.com/ commentisfree/2015/mar/24/migrants-leave-home-future-past-borders. 